\title{
INFLUENCE LIQUIDITY, ACTIVITY AND GROWTH TOWARD PROFITABILITY PERFORMANCE WITH LEVERAGE AND CASH FLOW AS INTERVENING VARIABLES Study in Type C Hospital at The PT Nusantara Sebelas Medika
}

\author{
Ainy Arga Astoety \\ Magister Manajemen, Fakultas Ekonomi dan Bisnis, Universitas 17 Agustus 1945 Surabaya \\ Email: ainyastoety@gmail.com \\ Tri Ratnawati \\ Magister Manajemen, Fakultas Ekonomi dan Bisnis, Universitas 17 Agustus 1945 Surabaya \\ Email :triratnawati@untag-sby.ac.id \\ Srie Hartutie Moehaditoyo \\ Magister Manajemen, Fakultas Ekonomi dan Bisnis, Universitas 17 Agustus 1945 Surabaya \\ Email :sriehartutiemoehaditoyo@gmail.com
}

Received: July 2019; Accepted: July 2019; Available online: July 2019

\begin{abstract}
The purpose of this study was to analyze financial ratios which included liquidity ratios, activity ratios, leverage ratios and profitability ratios to assess the financial performance of three type C hospitals managed by PT Nusantara Sebelas Medika. Data analyzed by Partial Least Square (PLS). The results in this study showed that Liquidity has insignificant effect on Leverage and cash flow. Activity also has insignificant effect on Leverage. Growth has insignificant on Cash Flow. Instead, growth was significant on leverage. Liquidity, activity and growth also have significant effect on profitability performance and support with positive influence direction in this study. Finally, leverage and cash flow have significant effect on profitability performance.
\end{abstract}

Keywords: liquidity ratio, financial leverage, activity ratio, profitability ratio, financial performance.

\begin{abstract}
Abstrak
Tujuan penelitian ini adalah menganalisis rasio keuangan yang meliputi rasio likuiditas, rasio aktivitas, rasio leverage dan rasio profitabilitas untuk menilai kinerja keuangan tiga rumah sakit tipe C yang dikelola oleh PT Nusantara Sebelas Medik. Data dianalisis dengan menggunakan Partial Least Square (PLS). Hasil dalam penelitian ini menunjukkan bahwa likuiditas tidak berpengaruh signifikan terhadap leverage dan cash flow. Aktivitas tidak berpengaruh signifikan terhadap leverage dan pertumbuhan juga tidak berpengaruh signifikan terhadap cash flow, sedangkan pertumbuhan berpengaruh signifikan terhadap leverage. Likuiditas, aktivitas, dan pertumbuhan terbukti berpengaruh signifikan terhadap kinerja profitabilitas dan mendapatkan dukungan dengan arah pengaruh yang positif di dalam penelitian ini. Leverage, cash flow berpengaruh signifikan terhadap kinerja profitabilitas.
\end{abstract}

Kata Kunci: rasio likuiditas, leverage, rasio aktivitas, rasio profitabilitas, kinerja keuangan.

How to Cite: Astoety, A. A., Ratnawati, T., \& Moehaditoyo, S. H. (2019). Liquidity, Activity, and Growth Influence Toward Profitability Performance with Leverage Variable and Cash Flow as Intervening Variable In Type "C" Hospital at The PT Nusantara Sebelas Medika. Media Ekonomi dan Manajemen, 34(2), 206-216. 


\section{INTRODUCTION}

One important aspect that must also be assessed from hospital organization is the financial aspect. However, because there is no specific standard for hospital accounting so the standard refers to the Financial Accounting Standards in general, including the Statement of Financial Accounting Standards No. 45 concerning Non-Profit Organizations. Based on PSAK No. 45 and PARS, in general the financial statements produced by hospitals include financial position reports at the end of the reporting period or called balance sheets, activity reports in lieu of income statements, cash flow reports and changes in equity reports for a reporting period, and notes on financial statements. One of the posts listed in the activity report is income. This post is measure of the success of the company's operational activities for a period. The right accounting treatment is very necessary in recognizing the income so that the amount of income is presented correctly. Revenues presented correctly help measure the right operational performance because measurements are carried out with reliable financial information.

PT Nusantara Sebelas Medika type C Hospital is hospital that is able to provide limited sub-specialist medical services. There are four types of specialist services provided, namely internal disease services, surgical services, child health services, and obstetrics and gynecological services. With increasing growth and competition requires hospital management to be able to look far ahead in anticipating various possibilities that can affect the development of hospitals, among others, by applying accountability accounting. By implementting good accountability accounting system, it will create control and measurement of work performance. Accountability accounting is system that measures the various results achieved by each center of accountability according to the information needed by managers to operate the center of accountability as part of the mana- gement control system. This system was created to provide managers the flexibility to manage the parts of the organization they lead optimally as a model of decentralization. The wider the organization, the more authority and responsibility is delegated to lower level management as form of decentralization

One of authority delegation forms is the establishment of various areas of responsibility known as the responsibility center. Responsibility Center is a business segment whose managers are responsible for series of certain activities (Hansen \& Mowen, 2005). There are four main types of responsibility centers, namely: Cost Centers, Revenue Centers, Profit Centers, and Investment Centers.

Assessment of financial aspects of hospital can be done by analyzing hospital financial statements, analyzing the financial ratios of hospitals. This financial ratio analysis is one of the strategic financial efforts to support the hospital strategy. Financial ratios are analytical tools to explain the relationship between one element and another element in financial statement. The financial statements in question are the balance sheet and income statement. The balance sheet describes the position of assets, debt, and equity owned by the company at any given moment. The income statement reflects the results achieved by the company for a certain period. According to Kasmir (2015), states that financial ratios are: activities comparing the numbers in the financial statements by dividing one number by another number. Comparisons can be made between one component with components in one financial report or between components that exist between financial statements. In this study include aspects of liquidity, activity, growth, leverage, cash flow and profitability.

Previous studies found different result (research gap) among researchers. Research conducted by Hombing and Hadi (2019) stated that liquidity has a positive and significant effect on profitability, but 
sales growth and working capital turn over did not affect on profitability. Research study by Prabowo and Sutanto (2019), Sukmayanti and Triaryatini (2019), Maria, Wiagustini \& Sedana (2019) stated that liquidity had negative effect toward profitability.

Study by Suwandi, Thalia, Syakina, Munawarah, and Aisyah (2019) showed that activity rasio didn't have significant effect on profitability. Instead, research by Mufidah and Azizah (2018) concluded that activity rasio had significant effect on profitability.

Study Affifah and Lisiantara (2019), showed that sales growth had inflluence effect on profitability. While research by Hombing and Teguh (2019) showed that sales growth didn't have influence on profitability.

Based on the background and research gap from previous researches, this is purposed to analyse and interpret the significant influence of liquidity ratio to leverage ratio; ratio of liquidity to cash flow ratio; ratio of activity to leverage ratio; ratio of activity to cash flow ratio; ratio of growth to leverage ratio; ratio of growth to cash flow ratio; ratio of liquidity to profitability performance; ratio of activity to profitability performance; ratio of growth to profitability performance; leverage ratio to cash flow ratio; leverage ratio to profitability performance; cash flow ratio against profitability performance.

\section{LITERATURE REVIEW Liquidity}

According to Horne and Wachowicz (2012), liquidity is ratio used to measure a company's ability to fulfill its short-term obligations. This ratio compares short-term liabilities with short-term resources (current assets) available to meet these short-term obligations. Whereas according to Hanafi and Halim (2009) liquidity is the ability of the company's short-term liquidity by looking at the amount of current assets relative to its current debt.
Previous researches supported for this study, such as Hombing and Teguh (2019) stated that liquidity has a positive and significant effect on profitability.

\section{Activity Ratio}

According to Sartono (2005) activity ratio is ratio that shows how resources have been used optimally, then by comparing the ratio of activities, it can be seen the level of efficiency of companies in the industry. Based on the results of simultaneous hypothesis testing, obtained a significant effect on profitability. Mufidah \& Azizah (2018) stated that activity ratio has positive effect on profitability with the test results of the determination coefficient of $34.5 \%$. While based on the results of partial hypothesis testing, inventory turnover, debt to equity ratio, working capital turnover, current ratio and receivable turnover have no significant effect (Suwandi, et al . 2019)

\section{Growth}

Sales growth reflects the success of investment in the past period and can be used as a prediction of future growth. Sales growth is an indicator of the demand and competitiveness of companies in an industry. The growth rate of a company will affect the ability to maintain profits in marking opportunities in the future. According to Swastha (2009), sales growth is an important indicator of market acceptance of the company's products and / or services, where income generated from sales can be used to measure the level of sales growth. Thus it can be seen that a company can be said to experience growth in a better direction if there is a consistent increase in the main activities of its operations. So, growth that occurs in trading companies is often said to be the level of sales growth. Study Mufidah \& Azizah (2018) states that the activity ratio affects profitability.

Based on the reference to the theoretical foundation and previous research, the conceptual framework in this study is as Figure 1. 


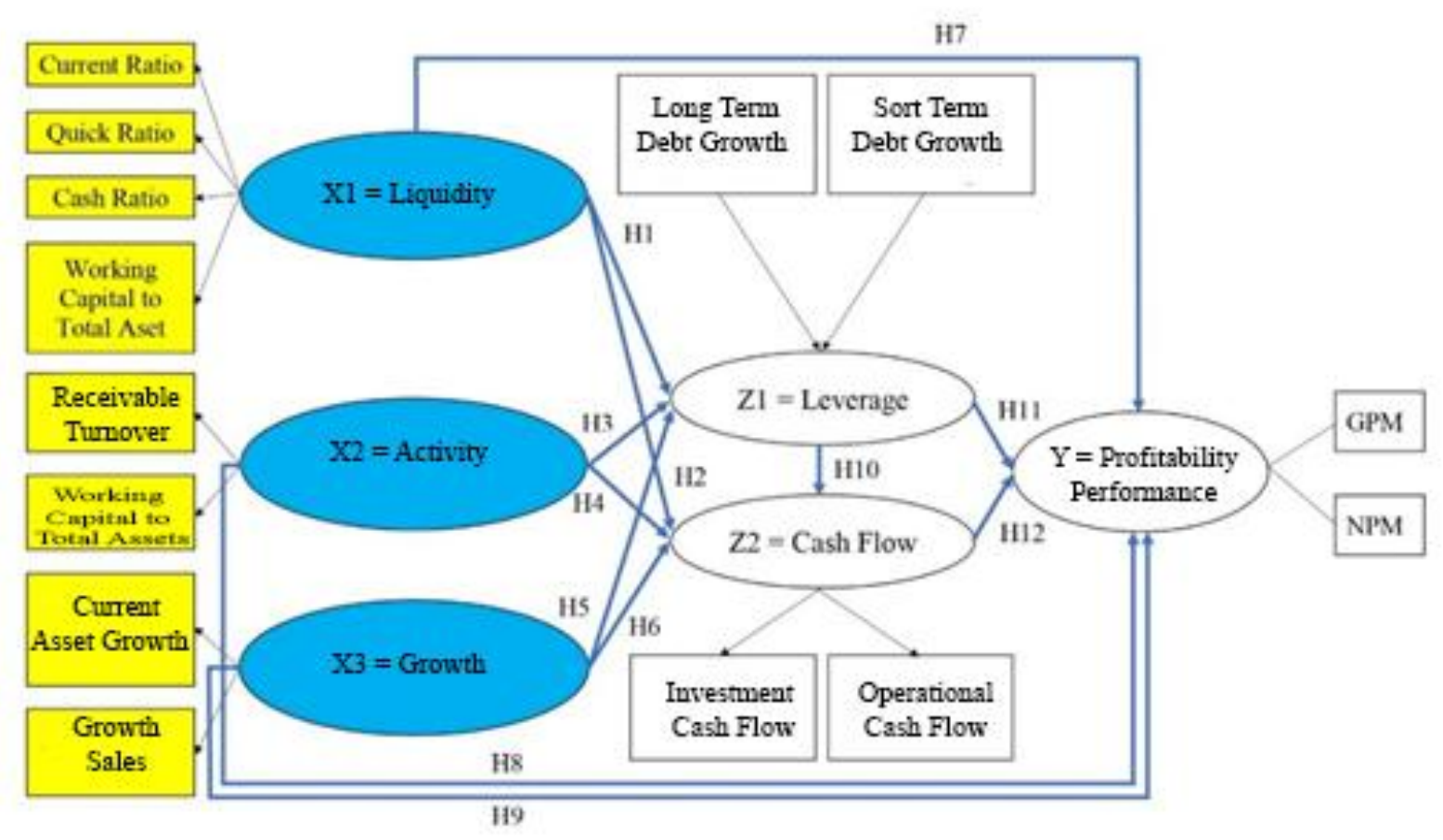

Figure 1. Conceptual framework

\section{RESEARCH METHODS}

Research type that used in this study is quantitative research with descriptive approach. Quantitative research method is one type of research whose specifications are systematic, planned and structured clearly from the beginning to the making of the research design. According to Sugiyono (2017), quantitative research methods can be interpreted as research methods that are based on the philosophy of positivism, used to examine certain populations or samples, sampling techniques are generally done randomly, data collection uses research instruments, quantitative data analysis / statistics with the aim to test the predetermined hypothesis

Population in this study consisted of 3 type C hospitals under PT Nusantara Sebelas Medika. The sample in this study is the whole of the population that is as many as 3 type $\mathrm{C}$ hospitals under the environment of PT Nusantara Sebelas Medika.

Liquidity is the company ability to fulfill its financial obligations that must be fulfilled immediately (short term). In this study the liquidity ratio is measured using the formula: According to Kasmir (2012) there are several types of methods of measuring liquidity ratios, as follows:

$$
\begin{aligned}
& \text { Current ratio }=\frac{\text { Current Asset }}{\text { Current Liabilities }} \times 100 \% \\
& \text { Quick ratio }=\frac{\text { Current Asset - Inventory }}{\text { Current Liabilities }} \times 100 \% \\
& \text { Cash ratio }=\frac{\text { Cash or cash equivalen }}{\text { Current Liabilities }} \times 100 \%
\end{aligned}
$$

The activity ratio is the ratio used to see the size of the company's effectiveness in using assets owned by the company. In activity ratios, analysis can be done using the following ratios:

$$
\begin{gathered}
\text { Receivable turn over }=\frac{\text { Credit sales }}{\text { Receivable }} \\
\text { Inventory turn over }=\frac{\text { Cost of goods sold }}{\text { Sales average }}
\end{gathered}
$$

Growth is variable that explains the company's growth prospects in the future. In this study growth can be calculated using: 
Sales Growth $=\frac{\mathrm{S} 1-\mathrm{S} 0}{\mathrm{~S} 0} \times 100 \%$

Current Asset Growth $=\frac{\mathrm{CA} 1-\mathrm{CA} 0}{\mathrm{CA} 0} \times 100 \%$

Leverage is measuring how much the company is financed with debt. In this study using:

$$
\begin{aligned}
& \text { Short }- \text { term Debt Growth }=\frac{\text { STL1 }- \text { STL0 }}{\text { STL0 }} \times 100 \% \\
& \text { Long }- \text { term Debt Growth }=\frac{\text { LTL1 }- \text { LTL0 }}{\text { LTL0 }} \times 100 \%
\end{aligned}
$$

Cash reflects purchasing power that can be transferred immediately in an economic exchange to each individual or organization for their particular needs in obtaining goods and services desired by them and available in the economy. In this study Cash Flow was measured using:

$$
\begin{aligned}
& \text { Funding Cash Flow (AKP) }=\frac{\mathrm{AKP}_{\mathrm{t}}-\mathrm{AKP}_{\mathrm{t}-1}}{\mathrm{AKP_{t-1 }}} \times 100 \% \\
& \text { Operational Cash Flow }(\mathrm{AKO})=\frac{\mathrm{AKO}_{\mathrm{t}}-\mathrm{AKO}_{\mathrm{t}-1}}{\mathrm{AKO} O_{t-1}} \times 100 \%
\end{aligned}
$$

Profitability is a ratio to assess a company's ability to seek profits. This ratio also gives measure of the effectiveness of a company's management. This is indicated by profits generated from sales and investment income. The point is that the use of this ratio shows company efficiency. In this study measured using:

$$
\text { Net Profit Margin }(N P M)=\frac{\text { EAIT }}{\text { Sales }}
$$

$$
\text { Gross Profit Margin }(\text { GPM })=\frac{\text { Gross profit }}{\text { Net sales }}
$$

To test the validity of this research hypothesis used Partial Least Square (PLS) analysis. There are two outputs in the PLS analysis, namely: outer model and inner model. Outer model are measure validity and reliability test instruments. Validity test through convergent validity and discriminant validity, and reliability test using composite reliability and Average Variance Extracted or AVE. Inner model used to determine the influence between variables and the hypothesis test. Assess RSquare using Smart-PLS to measure influences among variables, and hypothesis testing through Statistical Ttest. Inner model also to assess the amount of direct, indirect and total influence.

\section{RESULT AND DISCUSSION Measurement Model}

An indicator is declared as valid if it has loading factor above 0.5 (Ghozali, 2012). In the empirical experience of research, the value of the loading factor> 0.5 is still acceptable. Thus, the value of the loading factor $<0.5$ must be excluded from the model against the intended construct. The SmartPLS output for loading factors show in Figure 2.

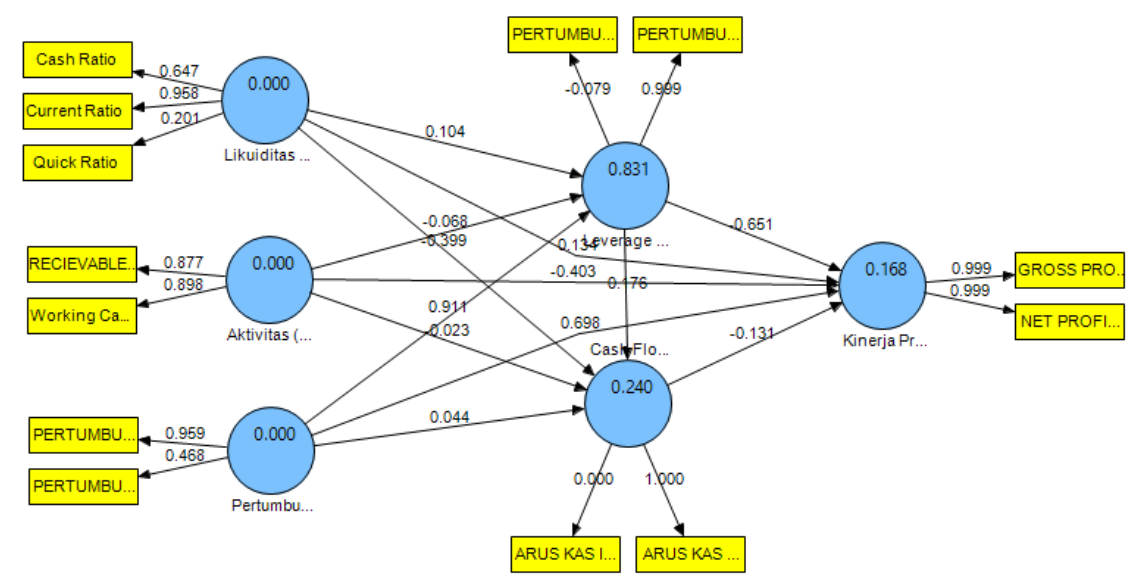

Figure 2. Values of Loading Factor Original 
Table 1. Result For Outer Loading

\begin{tabular}{llcc}
\hline \multicolumn{1}{c}{ Variables } & \multicolumn{1}{c}{ Indicator } & Loading Factor & Explanation \\
\hline \multirow{2}{*}{ Liquidity (X1) } & Cash Ratio & 0.647102 & Valid \\
\cline { 2 - 4 } & Current Ratio & 0.957921 & Valid \\
\cline { 2 - 4 } & Quick Ratio & 0.201271 & Invalid \\
\hline \multirow{2}{*}{ Activity (X2) } & Receivable Turnover & 0.877309 & Valid \\
\cline { 2 - 4 } & Working Capital to Total Assets & 0.897924 & Valid \\
\hline \multirow{2}{*}{ Growth (X3) } & Current Asset Growth & 0.959484 & Valid \\
\cline { 2 - 4 } & Growth Sales & 0.468296 & Invalid \\
\hline \multirow{2}{*}{ Leverage (Z1) } & Long Term Debt Growth & -0.079238 & Invalid \\
\cline { 2 - 4 } & Short Term Debt Growth & 0.999074 & Valid \\
\hline \multirow{2}{*}{ Cash Flow (Z2) } & Investment Cash Flow & 0.00000 & Invalid \\
\cline { 2 - 4 } & Operational Cash Flow & 1.000000 & Valid \\
\hline \multirow{2}{*}{ Profitability Performance (Y) } & Gross Profit Margin & 0.999269 & Valid \\
\cline { 2 - 4 } & Net Profit Margin & 0.999200 & Valid \\
\hline
\end{tabular}

Source: Secondary Data Processed by PLS 2.0, 2019

Based on the Table 1, it can be seen that not all proxies have the value of the outer loading factor greater than 0.5. so that the value of the outer loading factor of less than 0.5 is assumed to be less feasible to be used as an indicator that can reflect each of the corresponding variables

To obtain optimal results, the proxies that cannot reflect predetermined variables are eliminated and recalculations of the outer loading value are performed. The following Figure 3 and Table 2 illustrates the reflective value of the indicators for each variable after elimination for indicators that have value of the outer loading factor smaller than 0.5 .

Table 2 shows that the loading factor gives value above the recommended value of 0.5 (Ghozali, 2012). This means that the indicators used in this study are valid or have met convergent validity. Discriminant validity reflective indicators can be seen in cross-loading between indicators and their constructs using PLS Algorithm report select discriminated validity then cross loading and the following output SmartPLS.

Discriminant validity is measured by comparing the value of square root Average Variance Extracted (AVE) of each construct with a correlation between other constructs in the model. AVE values must be greater than 0.50 or have $p$-value smaller than the 5\% significance level. The results of discriminant validity measurements in this study can be seen in the following Table 3 . It gives the value of Average Variance Extracted (AVE) above 0.5 for all variables contained in the research model (Ghozali, 2012).

Reliability testing is done by looking at the Composite Reliability value of the indicator block that measures the construct. The Composite Reliability results will show satisfactory value if above 0.7 . Table 4 shows that the composite reliability value for all variables above 0.7 indicates that all variables in the estimated model has high reliability so they meet the criteria of discriminant validity (Ghozali, 2012).

\section{Testing of Inner Model}

After the estimated model meets the Outer Model criteria, then the structural model (Inner model) is tested. R Square (R2), often referred to as the coefficient of determination, is measuring goodness of fit from the regression equation; that is giving the proportion or percentage of total variation in the dependent variable explained by the independent variable. R2 value is located between $0-1$, and the 
suitability of the model is said to be better if $\mathrm{R} 2$ is getting closer to 1 .

Base on Table 5, liquidity, activity and growth can be explained leverage of $84.5 \%$, liquidity, activity, growth and leverage can be explained by cash flow of $21.4 \%$, and liquidity, activity, growth, leverage and cash flow are able to explain profitability performance of $12.3 \%$.

To prove the hypothesis that is by looking at the influence significance between variables by looking at the parameter coefficients and the significance value of $t$ statistics. In PLS2.0 this is done by looking at the Boostrapping report Algorithm (Figure 4).
Based on Table 6, path coefficient shows there are seven significance effect, that are growth toward cash flow, growth toward leverage, liquidity toward profitability performance, activity toward profitability performance, growth toward profitability performance, leverage toward cash flow, leverage toward profitability performance, and cash flow toward profitability performance, with a significance probability value less than 0.05 . Result study also show there are five insignificant effect, that activity toward cash flow, activity toward leverage, liquidity toward cash flow, liquidity toward leverage, and growth toward cash flow.

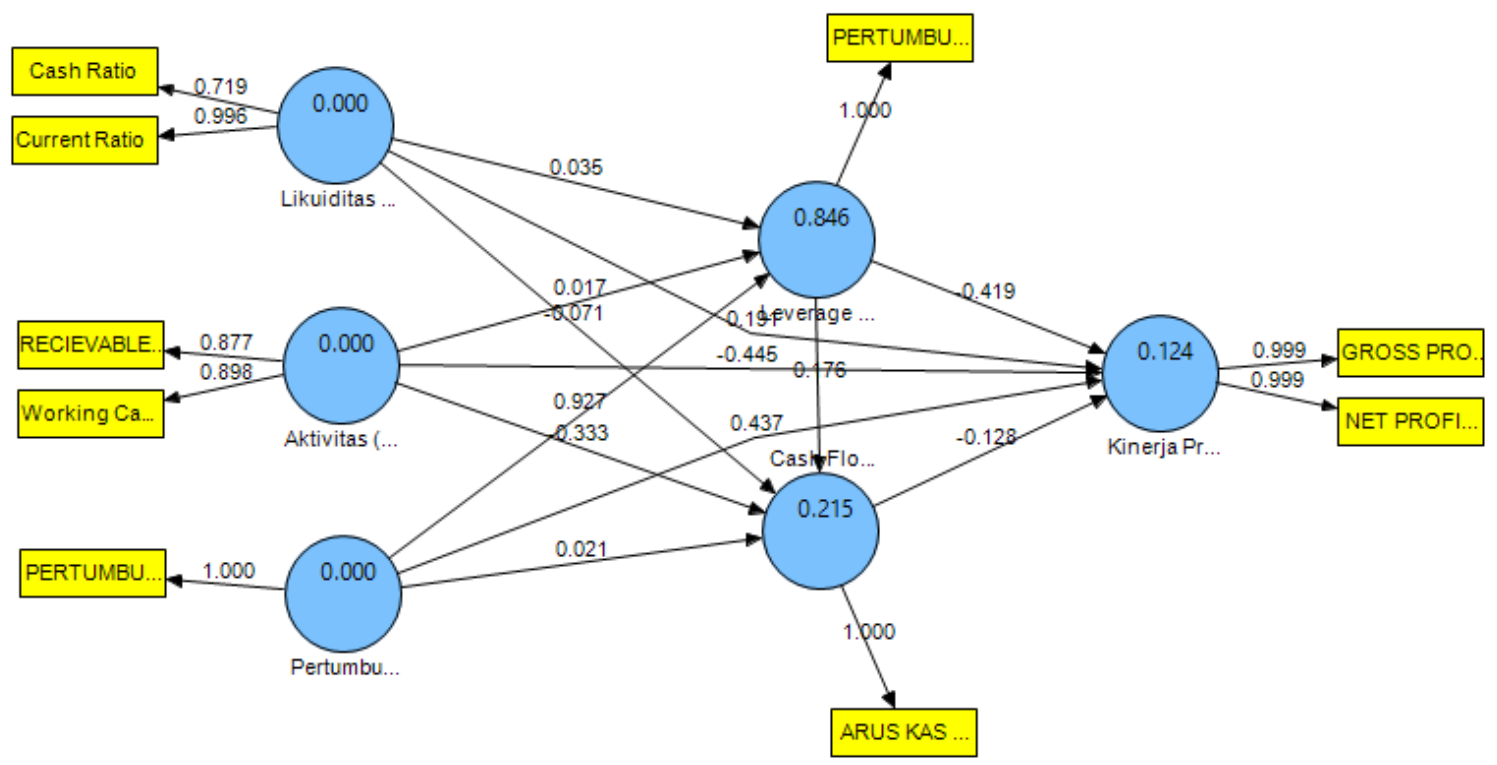

Figure 3. Values of Loading Droping Finish

Table 2. Result For Outer Loading Dropping

\begin{tabular}{|c|c|c|c|}
\hline Variables & Indicator & Loading Factor & Explanation \\
\hline \multirow{2}{*}{ Liquidity (X1) } & Cash Ratio & 0.718821 & Valid \\
\hline & Current Ratio & 0.996423 & Valid \\
\hline \multirow{2}{*}{ Activity (X2) } & Receivable Turnover & 0.877064 & Valid \\
\hline & Working Capital to Total Assets & 0.898149 & Valid \\
\hline Growth (X3) & Current asset growth & 1.000000 & Valid \\
\hline Leverage (Z1) & Short term debt growth & 1.000000 & Valid \\
\hline Cash Flow (Z2) & Operational cash flow & 1.000000 & Valid \\
\hline \multirow{2}{*}{$\begin{array}{l}\text { Profitability } \\
\text { performance (Y) }\end{array}$} & Gross Profit Margin & 0.999292 & Valid \\
\hline & Net Profit Margin & 0.999175 & Valid \\
\hline
\end{tabular}

Source: Secondary Data Processed by PLS 2.0, 2019 
Table 3. Average Variance Extracted (AVE)

\begin{tabular}{lcc}
\hline \multicolumn{1}{c}{ Variables } & AVE (Initial Model) & AVE (Elimination) \\
\hline Activity (X2) & 0.787970 & 0.787956 \\
Cash Flow (Z2) & 0.500000 & 1.000000 \\
Profitability Performance (Y) & 0.998469 & 0.998468 \\
Leverage (Z1) & 0.502214 & 1.000000 \\
Liquidity (X1) & 0.458955 & 0.754781 \\
Growth (X3) & 0.569956 & 1.000000 \\
\hline
\end{tabular}

Source: Secondary Data Processed by PLS 2.0, 2019

Table 4. Composite Reliability

\begin{tabular}{lcc}
\hline \multicolumn{1}{c}{ Variables } & $\begin{array}{c}\text { Composite Reliability } \\
\text { (Initial Model) }\end{array}$ & $\begin{array}{c}\text { Composite Reliability } \\
\text { (Elimination) }\end{array}$ \\
\hline Activity (X2) & 0.881399 & 0.881390 \\
Cash Flow (Z2) & 0.500000 & 1.000000 \\
Profitability Performance (Y) & 0.999234 & 0.999233 \\
Leverage (Z1) & 0.459419 & 1.000000 \\
Liquidity (X1) & 0.667787 & 0.857119 \\
Growth (X3) & 0.703279 & 1.000000 \\
\hline
\end{tabular}

Source: Secondary Data Processed by PLS 2.0, 2019

Table 5. R-Square

\begin{tabular}{lcc}
\hline \multicolumn{1}{c}{ Variables } & $\begin{array}{c}\text { R Square } \\
\text { (Initial Model) }\end{array}$ & $\begin{array}{c}\text { R Square } \\
\text { (Elimination) }\end{array}$ \\
\hline Leverage (Z1) & 0.830613 & 0.845628 \\
Cash Flow (Z2) & 0.240069 & 0.214884 \\
Profitability Performance (Y) & 0.167875 & 0.123725 \\
\hline
\end{tabular}

Source: Secondary Data Processed by PLS 2.0, 2019

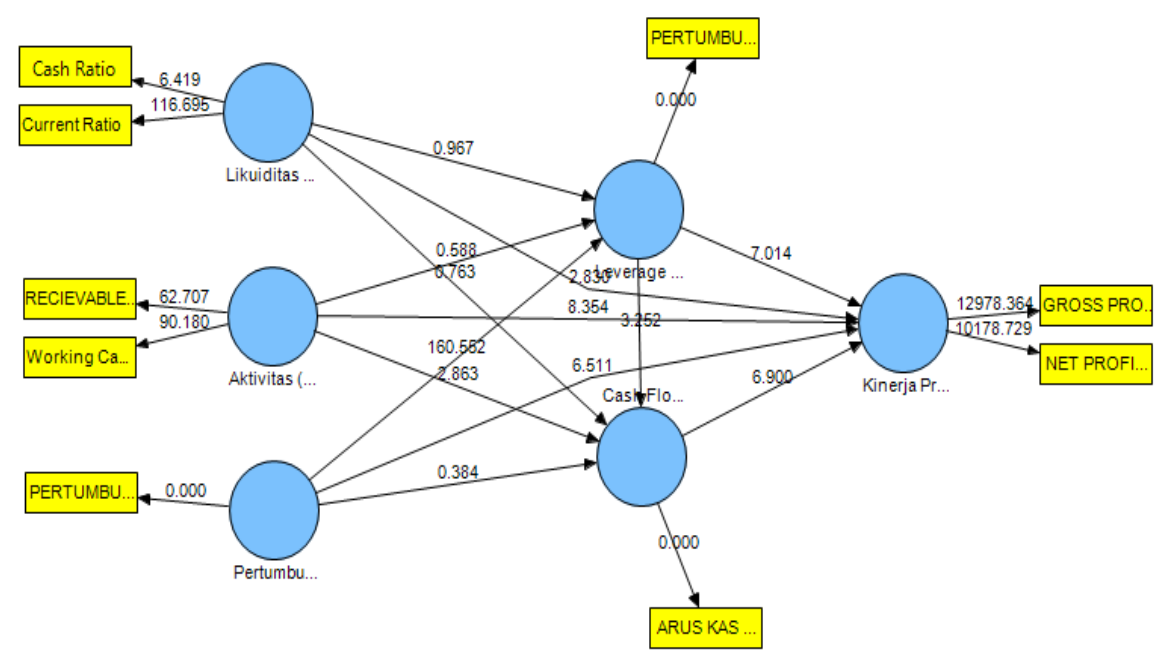

Figure 4. Algorithm Boostrapping Report 
Table 6. Testing Relationship between Variables

\begin{tabular}{cccccc}
\hline Hypotheses & Effect & Coefficient & S.E. & t-Statistics & Explanation \\
\hline 1 & $\mathrm{X} 1 \rightarrow \mathrm{Z} 1$ & 0.035034 & 0.036227 & 0.967059 & Insignificant \\
2 & $\mathrm{X} 1 \rightarrow \mathrm{Z} 2$ & -0.071084 & 0.093176 & 0.762901 & Insignificant \\
3 & $\mathrm{X} 2 \rightarrow \mathrm{Z} 1$ & 0.017262 & 0.029380 & 0.587545 & Insignificant \\
4 & $\mathrm{X} 2 \rightarrow \mathrm{Z} 2$ & -0.333394 & 0.116457 & 2.862814 & Significant \\
5 & $\mathrm{X} 3 \rightarrow \mathrm{Z} 1$ & 0.927233 & 0.005775 & 160.552041 & Significant \\
6 & $\mathrm{X} 3 \rightarrow \mathrm{Z} 2$ & 0.020817 & 0.054151 & 0.384430 & Insignificant \\
7 & $\mathrm{X} 1 \rightarrow \mathrm{Y}$ & 0.191034 & 0.067497 & 2.830265 & Significant \\
8 & $\mathrm{X} 2 \rightarrow \mathrm{Y}$ & -0.444814 & 0.053247 & 8.353724 & Insignificant \\
9 & $\mathrm{X} 3 \rightarrow \mathrm{Y}$ & 0.436631 & 0.067058 & 6.511271 & Significant \\
10 & $\mathrm{Z} 1 \rightarrow \mathrm{Z} 2$ & 0.175531 & 0.053978 & 3.251872 & Significant \\
11 & $\mathrm{Z} 1 \rightarrow \mathrm{Y}$ & -0.418581 & 0.059681 & 7.013681 & Significant \\
12 & $\mathrm{Z} 2 \rightarrow \mathrm{Y}$ & -0.127927 & 0.018539 & 6.900411 & Significant \\
\hline
\end{tabular}

Source: Secondary Data Processed by PLS 2.0, 2019

\section{Discussion}

The results of the study prove that liquidity does not have a significant effect on leverage, meaning that the company's ability to fulfill its short-term obligations does not affect the use of sources of funds that have a fixed burden to finance the investment of a company. The hospital is one of the business units of PT Nusantara Sebelas Medika which is a profit center, all revenue is cashed in to the head office, so all hospital obligations are the responsibility of the head office, which is settled by dropping working capital. Liquidity also has no effect on the flow rate, this is because all hospital Cash Flow needs are met by the head office of PT Nusantara Sebelas Medika. At the time of the National Health Insurance (Jaminan Kesehatan Nasional - JKN) era approximately $80 \%$ of hospital income is from BPJS patients, whose payment is 3 months after service, so that it can only be cashed into the campus after liquid, while the hospital's daily operations are funded by dropping capital work from the head office.

Activities also do not affect leverage or cash flow. Thus the increase in the value of Total Assets Turn Over (TATO) which describes how much support all assets have to obtain sales, then the company's profits should also increase. But this is not the case for health services in the JKN Era. Some hospital income has to be lost, because there are several diagnoses of the disease whose package of claims is loss.

There are seven significance effects, they are growth toward cash flow, growth toward leverage, liquidity toward profitability, performance toward profitability of performance, growth toward profitability performance, leverage toward cash flow, leverage toward profitability performance, and cash flow toward profitability performance. This result supported previous study by Hombing and Hadi (2019), Mufidah and Azizah (2018), Affifah and Lisiantara (2019). The results of this study show the importance of aspects of liquidity, activity, growth, leverage, cash flow and profitability as an analytical tool to explain the relationship between one element with another element in a financial report in assessing the financial performance of a hospital.

\section{CONCLUSION}

Assessment of financial aspects of a hospital can be done by analyzing hospital financial statements with financial ratio analysis which is one of the strategic 
financial efforts in supporting the Hospital strategy. The sizes used in this study include: liquidity, activity, growth, leverage, cash flow, profitability. The actual problem faced by private hospitals in financial management is the existence of a National Health Insurance policy that influences the governance and financial health of hospitals. This study is expected Contributing to the theory of financial management especially in hospitals; Build a model of hospital's financial management strategy; and provide references and ideas for advanced research on the specific functions of hospital's financial management. The results of this study need to be followed up with a deeper study of the efforts of hospitals in dealing with the problems of national health insurance policies, improving regulation and the use of a better hospital financial governance system.

\section{REFERENCES}

Affifah, A. \& Lisiantara, G.A. (2019). Pengaruh Pertumbuhan Penjualan, Total Asset Turnover, Modal Kerja, dan Struktur Modal Terhadap Profitabilitas dan Ukuran Perusahaan Sebagai Variabel Kontrol pada Perusahaan Manufaktur yang Terdaftar di Bursa Efek Indonesia Periode Tahun 2015 - 2017. Students' Journal of Accounting and Banking, 8(1).

Baridwan, Z. (2004). Intermediate Accounting, Eighth edition, Yogyakarta: BPFE

Ghozali, I., \& Latan, H. (2012). Partial Least Squares, Konsep, Teknik Dan Aplikasi Menggunakan Program Smartpls 3.0 Untuk Penelitian Empiris. Semarang: Badan Penerbit UNDIP.
Hanafi, M. \& Halim, A. (2009). Analisis Laporan Keuangan.Yogyakarta : UPP STIM YKPN

Hansen, D. R., \& Mowen, M. M. (2005). Environmental cost management. Management accounting, 7, 490-526.

Horne, J. C. V., \& Wachowicz, J. M. (2012). Prinsip-prinsip manajemen keuangan. Jakarta: Salemba Empat.

Hombing,, A.M.Br., \& Hadi, T. P. (2019). Pengaruh Likuiditas, Pertumbuhan Penjualan, Perputaran Modal Kerja, Dan Leverage Terhadap Profitabilitas Pada Perusahaan Manufaktur Yang Terdaftar Di BEI Periode 2015-2017. Students' Journal of Accounting and Banking, 8(2).

Kasmir. (2015). Analisis Laporan Keuangan. Jakarta: Rajawali Pers.

Maria, M., Wiagustini, L. P., \& Sedana, I. P. (2019). Pengaruh Ukuran Perusahaan, Leverage Dan Liquiditas Terhadap Profitabilitas Di Perusahaan Esperanca Timor-Oan (ETO) Dili Timor-Leste. E-Jurnal Ekonomi dan Bisnis Universitas Udayana, 8(1), 23-40.

Mufidah, H. L., \& Azizah, D. F. (2018). Pengaruh Rasio Aktivitas Dan Rasio Leverage Terhadap Profitabilitas (Studi pada Perusahaan Sub Sektor Food and Beverages yang terdaftar di BEI Periode 2012-2016). Jurnal Administrasi Bisnis, 59(1), 1-7.

Prabowo, R., \& Sutanto, A. (2019). Analisis Pengaruh Struktur Modal, dan Likuiditas terhadap Profitabilitas pada Perusahaan Sektor Otomotif di indonesia. Jurnal Samudra Ekonomi dan Bisnis, 10(1), 1-11.

Sartono, A. 2005. Manajemen Keuangan: Teori dan Aplikasi. Yogyakarta: BPFE. 
Sugiyono. (2017). Qualitative Quantitative Research Methods and $R$ \& D., Bandung: Alfabeta.

Sukmayanti, N. W. P., \& Triaryati, N. (2019). Pengaruh Struktur Modal, Likuiditas dan Ukuran Perusahaan terhadap Profitabilitas pada Perusahaan Property dan Real Estate. E-Jurnal Manajemen, 8(1), 172-202.

Suwandi, S., Thalia, J., Syakina, S., Munawarah, M., \& Aisyah, S. (2019). Pengaruh Rasio Aktivitas, Solvabilitas dan Likuiditas terhadap Profitabilitas pada Perusahaan Pertambangan Batubara. Journal of Education, Humaniora and Social Sciences (JEHSS), 1(3), 182-188.

Swastha, B. (2009). Manajemen Pemasaran. Penerbit Liberty. 